\title{
LABEL ANALYSIS OF SERBIAN HONEY: WHAT DOES (NOT) THE LABEL TELL US?
}

\author{
Suzana Vidaković ${ }^{*}$, Jelena Babić1 ${ }^{1}$, Slobodan Knežević1 ${ }^{1}$, Miloš Pelić ${ }^{1}$, \\ Sandra Jakšić ${ }^{1}$, Brankica Kartalović ${ }^{1}$, Milica Živkov-Baloš ${ }^{1}$ \\ ${ }^{1}$ Scientific Veterinary Institute "Novi Sad", Novi Sad, Serbia
}

\begin{abstract}
In order to differentiate between many honey types on Serbian market, consumers read labels, which represent an important aspect of packaging "catching" the consumer's eyes as well as carrying all the necessary information about the product, producer and seller. As consumers are more and more aware of health problems and nutrition they pay attention to the information written on the labels on different products. The aim of this study was to inspect labels on honey packages collected in an official monitoring during October 2017. In total 60 honey samples were collected and examined. Of all examined honey samples, 46 (76.67\%) labels did not fulfill prescribed conditions according to Legislative on quality of honey and other bee products and Declaration, labeling and marketing of food ("Official Gazette RS”, No. 101/2015; “Official Gazette RS” No. 85/13 and No. 101/13), while only $14(23.33 \%)$ did. This results lead to indispensible need to inform and educate beekeepers about the actual laws and regulations in order to make labels that contain all the information required, which might possibly also raise the consumption of honey to higher level.
\end{abstract}

Key words: bee honey, bee products, market, monitoring

${ }^{1 *}$ Corresponding author: suzana@niv.ns.ac.rs 


\title{
PREGLED DEKLARACIJA SRPSKOG MEDA: ŠTA NAM (NE) GOVORE DEKLARACIJE?
}

\author{
Suzana Vidaković ${ }^{1 *}$, Jelena Babić ${ }^{1}$, Slobodan Knežević ${ }^{1}$, Miloš Pelić ${ }^{1}$, \\ Sandra Jakšić ${ }^{1}$, Brankica Kartalović ${ }^{1}$, Milica Živkov-Baloš ${ }^{1}$ \\ ${ }^{1}$ Naučni institut za veterinarstvo “Novi Sad”, Novi Sad, Srbija
}

\section{Kratak sadržaj}

U svrhu razlikovanja mnogobrojnih vrsta medova na tržištu Srbije potrošači čitaju deklaracije koje predstavljaju važan deo pakovanja privlačeći potrošače izgledom i dajući im neophodne informacije o proizvodu, proizvođaču i prodavcu. Mnogi potrošači vode računa o informacijama koje se nalaze na deklaracijama zbog brige o svom zdravlju i ishrani. Cilj ovog istraživanja bio je pregled deklaracija koje se nalaze na pakovanjima meda u službenom monitoringu sprovedenom u oktobru mesecu 2017. godine. U ovom istraživanju ispitano je 60 uzoraka meda. Od svih pregledanih uzoraka meda 46 (76.67\%) deklaracija nije bilo u skladu sa zahtevima Pravilnika o kvalitetu meda i drugih proizvoda pčela ("Službeni glasnik RS”, broj 101/2015) i Pravilnika o deklarisanju, označavanju i reklamiranju hrane (“Službeni glasnik RS” broj 85/13 i 101/13), dok je samo $14(23.33 \%)$ ispunjavalo zahteve. Ovi rezultati pokazuju potrebu za informisanje i edukaciju pčelara u skladu sa Pravilnicima. Naime, upotpunjavanje informacija na deklaracijama svakako može dovesti do povećanja konzumacije meda.

Ključne reči: pčelinji med, pčelinji proizvodi, tržište, monitoring

\section{INTRODUCTION}

Bees (Apis mellifera) collect nectar and transform it, combining it with their own specific substances, to the natural sweet substance called honey (“Official Gazette RS", 101/2015). The production of honey involves a wide range of factors acting together in perfect harmony (Prica et al., 2014). Moderate continental climate as well as floral and plant richness make perfect conditions for beekeeping in Serbia (Babić, 2014).

Honey and other bee products available on Serbian market should be labeled according to the Legislative on quality of honey and other bee products 
and Declaration, labeling and marketing of food ("Official Gazette RS", No. 101/2015; "Official Gazette RS" No. 85/13 and No. 101/13). The label has to be written on Serbian language. It must be easy to understand, visible, clear and easy to read (“Official Gazette RS" No. 85/13 and No. 101/13).

Proper labeling of honey and other bee products helps to provide the consumers with necessary information about products they purchase. Name of the food should be the one that is prescribed by law ("Official Gazette RS" No. $85 / 13$ and No. 101/13). The product may only be called "honey" if it complies with the prescribed compositional standards and has no other ingredient added to it. According to the origin, honey is classified as: blossom or nectar honey (monofloral and polyfloral honey), honeydew and baker's honey. It is classified as comb honey, chunk honey, drained honey, extracted honey, pressed honey and filtered honey according to type of production and/or presentation on market. All honey types, except baker's honey and filtered honey, may be labeled with additional information relating to its floral origin, its regional, territorial or topographical origin or its specific quality criteria. The name of honey has to be characterized by specific blossom or plant it originates from in such a way that, if there is any reference to a particular blossom or plant, the honey has to come wholly or mainly from that blossom or plant. Likewise, if reference is made to a regional, territorial or topographical origin the honey must come wholly from that country or place. Baker's honey must be labeled with the words "intended for cooking only" in close proximity to the name ("Official Gazette RS”, No. 101/2015).

Net mass on the label represents charging amount expressed with numerical value, either in weight liquid or units. Net mass of honey and honey products must be stated in grams $(\mathrm{g})$ or kilograms $(\mathrm{kg})$ as appropriate without the packaging (jar, lid, label, etc.). The mass marking should be shown in the same field of vision as the name of a food ("Official Gazette RS" No. 85/13 and No. 101/13).

The date of a minimum durability of certain food is defined as the date until which the food retains its specific properties if properly stored ("Official Gazette RS” No. 85/13 and No. 101/13). Honey should retain its specific properties for a number of years if correctly stored, therefore it's up to the beekeeper/honey packer to determine what a suitable shelf life for their product should be, taking into account the nature of the product. The optimal temperature for storing honey and bee products is $10-16^{\circ} \mathrm{C}$ with ambient relative humidity lower than 65\% (Bogdanov, 2009). Still, recommended shelf life for honey stored at room temperature is 1 (one) year, while opened honey, stored in refrigerator has shelf life from 6 to 8 months (Roberts and Graham, 2004). 
Every package of honey and/or bee product has to have a batch number on the label. Importance of batch number is shown in the definition of traceability. It represents the capacity to follow the whole life cycle (forward or backward) of any product, including food (Tatiana et al., 2013).

\section{MATERIALS AND METHODS}

In total, 58 honey samples and 2 bee products (acacia honey with curcuma and honey with walnuts) were collected from different retail chains in Vojvodina region (north Serbia). All samples were collected as a part of official monitoring of honey and bee products quality during October 2017.

All collected samples were, in their original packaging, transferred to the laboratory of Scientific Veterinary Institute "Novi Sad" for examinations. In order to analyze labels, every sample was inspected for the presence of name, classification according to origin and according to the ways of producing and placing on the market, net quantity, best use before/date of expiry and batch number.

A total of 60 investigated samples included 18 samples of acacia honey, 17 samples of meadow honey, 8 samples of floral honey, 6 samples of linden honey, 5 samples of honeydew honey, 2 sample of floral honey with honeydew, 2 bee products (acacia honey with curcuma and honey with walnuts), 1 sample of sunflower honey and 1 sample of acacia/baker's honey.

\section{RESULTS AND DISCUSSION}

According to both Legislative on quality of honey and other bee products and Declaration, labeling and marketing of food ("Official Gazette RS", No. 101/2015; "Official Gazette RS” No. 85/13 and No. 101/13), 46 (76.67\%) labels did not fulfill prescribed conditions, while only $14(23.33 \%)$ did.

In total, $44(73.33 \%)$ labels lack the information about classification according to origin, while only $15(25.00 \%)$ had that information. In this study, pollen analysis was not performed, but in studies carried out in Croatia during 2004 pollen analyses showed that $28.80 \%$ of honey samples did not match information about origin of honey provided on the labels, 14.60\% in 2005 (Peternel et al. 2006) and 20\% in 2012 (Hrga and Stjepanović, 2013). In our study, 1 (1.67\%) label classification according to the origin had double meaning.

All 52 (86.67\%) honey samples, which contained information about classification according to the type of production and/or presentation on market, have been labeled as extracted honey. The rest of the samples $(8(13.33 \%))$ lack this information. 
Net mass was indicated on 58 (96.67\%) inspected labels, while 2 (3.33\%) of them lacked this information.

Also, date of expiry was not indicated on $3(5.00 \%)$ inspected labels, while $5(8.33 \%)$ of them were with "unlimited" date of expiry. In previous studies it was found that the half life of diastase activity was 4 years at $20^{\circ} \mathrm{C}$, while the time needed for formation of $40 \mathrm{mg} / \mathrm{kg} \mathrm{HMF}$ (hydroxymethylfurfural) in honey was 2 to 4 years (Bogdanov, 2009). In addition, honey is highly hygroscopic substance, and its moisture content may vary depending on air humidity during storage (Prica et al., 2014).

Total of $13(21.67 \%)$ labels were without information about the batch number. In a study from Romania, the authors have shown that approximately $80 \%$ of the respondents are ready to pay an extra bid for honey with a traceability system (Tatiana et al., 2013).

The lack of information on labels in Serbian market are probably because Serbian beekeepers usually use direct marketing, which allows them to keep most of the price for themselves and to make direct contact with customers, which lead to customer loyalty (Zarić et al., 2013). In a study conducted in Vojvodina region in 2014, 40.6\% of the respondents said that they purchase honey directly from beekeepers. The reason for this was big confidence in the producers, lower price than in stores and belief in higher quality (Ćirić et al., 2015). In Poland, $78 \%$ of the respondents said that the honey from a beekeeper was somehow "better" than the ones offered in the stores (Roman et al., 2013).

Although none of the legislation considers honey as a major allergen and none of the inspected labels contained information about allergen (including honey with walnuts), many studies showed that both pollen and insect allergen activity was found in all types of honey (Helbling et al., 1992; Kiistala et al., 1995).

Earlier, honey was used in the nutrition of children, but lately there is a health concern for infants regarding the presence of Clostridium botulinum in honey (Bogdanov et al., 2008). According to several authors, honey should not be given to children under 12 months of age (Tanzi et al., 2002; Aureli et al., 2002). Although this information seems to be very important, both consumers and beekeepers from Serbia may not be informed enough, due to a lack of this information in public media and legislation. Consequently, none of the inspected labels contained any information about infant's consumption of the honey. 


\section{CONCLUSION}

The importance of tracing and tracking honey and/or bee products by batch number in every step of its production life cycle as well as in the market to ensure the final safety and quality is important and useful in increasing consumers trust. The quality of honey and bee products depends on its origin. The active components in plants depend on various factors and climatic conditions in different geographical locations. Choosing the honey from a certain location could have many nutritional and health benefits. Honey, as the potentially allergenic substance containing pollen and insect allergens, can be the cause of serious health problems in some people/children. Honey is an excellent energy source, but not recommended in diets of children under 12 months of age because of potential presence of Clostridium botulinum.

The shelf life of honey has to be based on the analysis of the quality of honey such as diastase activity and HMF content. Beekeepers have to be aware of the potential risks with improper storage conditions of honey and bee products.

It is common knowledge that "the customers buy with their eyes". Therefore, it is important that offered honey and bee products are properly packaged in aesthetic, eye-catching packaging. A colored label completes the whole image of the product. It carries the necessary information on the composition of the product, and can bring the consumption of the honey to a higher level.

\section{ACKNOWLEDGEMENT}

The research was supported by the Ministry of Education Science and Technological Development, Republic of Serbia, Projects Number TR 31084 and TR 31071.

\section{REFERENCES}

1. Aureli P., Franciosa G., Fenicia L.: Infant botulism and honey in Europe: a commentary. The Pediatric infectious disease journal, 21, 9, 866-868, 2002.

2. Babić J.: Kvalitet meda u prometu, Naučni institut za veterinarstvo „Novi Sad“, 2014.

3. Bogdanov S., Jurendic T., Sieber R., Gallmann P.: Honey for nutrition and health: a review. Journal of the American College of Nutrition, 27, 6, 677689, 2008.

4. Bogdanov, S.: Storage, Crystallisation and Liquefaction of Honey. In: The Honey Book, Bee Product Science, 2009. 
5. Ćirić M., Ignjatijević S., Cvijanović D.: Research of honey consumers' behavior in province of Vojvodina. Economics of Agriculture, 62, 3, 627-644, 2015.

6. Helbling, A., Peter, C. H., Berchtold, E., Bogdanov, S., Müller, U.: Allergy to honey: relation to pollen and honey bee allergy, Allergy, 47, 1, 41-49, 1992.

7. Hrga I., Stjepanović B.: Melissopalynological characteristics of the most important types of honey in the Republic of Croatia. In: Dražen Lušić; Sandra Pavičić Žeželj, editor, Zbornik sažetaka, 3th National Conference on the Safety And Quality of the Beehive Products: Novel Trends, 22. March, Opatija, Rijeka, Medicinski fakultet Sveučilište u Rijeci, Katedra za zdravstvenu ekologiju, 2013.

8. Kiistala R., Hannuksela M., Mäkinen-Kiljunen S., Niinimäki A., Haahtela T.: Honey allergy is rare in patients sensitive to pollens. Allergy, 50, 10, 844-847, 1995.

9. Peternel R., Lasić D., Puntarić D., Čulig J.: Malisopalinologija in practice. In: Saša Haberle, editor, Zbornik radova, 31. stručni skup s međunarodnim sudjelovanjem Zdravstvena ekologija u praksi, 10-12. May, Šibenik, Zagreb: 2006.

10. Prica N., Živkov-Baloš M., Jakšić S., Mihaljev Ž., Kartalović B., Babić J., Savić S.: Moisture and acidity as indicators of the quality of honey originating from Vojvodina region. Archives of veterinary medicine, 7, 2, 99-109, 2014.

11. Roberts T., Graham P. P.: Food storage guidelines for consumers, 2004.

12. Roman A., Popiela-Pleban E., Kozak M., Roman K.: Factors influencing consumer behavior relating to the purchase of honey part 2. Product quality and packaging. Journal of Apicultural Science, 57, 2, 175-185, 2013.

13. Rulebook on Declaration, Labeling and Marketing of Food ("Official Gazette RS" No. 85/13 and No. 101/13).

14. Rulebook on quality of honey and other bee products ("Official Gazette RS”, No. 101/2015).

15. Tanzi M. G., Gabay M. P.: Association between honey consumption and infant botulism, Pharmacotherapy. The Journal of Human Pharmacology and Drug Therapy, 22, 11, 1479-1483, 2002.

16. Tatiana B., Arion F., Muresan I.: Romanian premium honey consumer's perceptions about traceability. Agriculture - Science and Practice Journal, 85, 1/2, 104-111, 2013.

17. Zarić V., Vasiljević Z., Nedić N., Petković D.: The marketing strategies of Serbian honey producers. Applied Studies in Agrobusiness and Commerce, 7, 2/3, 27-31, 2013. 